\title{
Anti-Bacterial and Anti-Fungal Activities from Macaranga bancana Leaves Extract
}

\author{
Rianti Putri, Rudi Hendra, Hilwan Y. Teruna \\ Department of Chemistry, Faculty of Mathematics and Natural Sciences, \\ University of Riau, Pekanbaru, Riau, Indonesia \\ Scientific Consortium of Drug Discovery and Development, University of Riau, \\ Pekanbaru, Riau, Indonesia
}

\begin{abstract}
Macaranga bancana is one of the Indonesian medicinal plants that is empirically used to treat infectious disease. The aim of this study was to evaluate anti-bacterial and antifungal activities of $M$. bancana against human pathogenic microbes, i.e., Escherichia coli, Staphylacoccus aureus, and Candida albicans. The dried leaves of M. bancana were extracted using cold extraction method with n-hexane, dichloromethane, ethylacetate, methanol, and ethanol solvents. The evaluation of anti-microbial activity from these extracts at the concentration of $1000 \mu \mathrm{g} / \mathrm{ml}$ was conducted using microdilution method. Amoxicillin, cephadroxil, and ketoconazole were used as positive controls. All extracts showed $100 \%$ inhibitory activity against $S$. aureus, with the exception of ethanol extract which was $72.8 \%$. Nevertheless, methanol and ethanol extracts showed $100 \%$ inhibitory activity against $E$. coli, while the lowest activity was shown by n-hexane extract ( $45.2 \%)$. All extracts exhibited $100 \%$ inhibitory activity against $C$. albicans. In conclusion, leaves extract of $M$. bancana is a potential source of anti-bacterial and anti-fungal agents.
\end{abstract}

Keywords: anti-bacterial, anti-fungal, $M$. bancana, microdilution

\section{Introduction}

The irrational use of antibiotics cause many pathogenic microbes to adapt to their environment and become resistant to synthetic antibiotic drugs. This has encouraged the development of novel antimicrobial substances derived from natural products. ${ }^{1} M$. bancana plant, a member of Euphorbiaceae family, is widely found in Indragiri Hulu, Province of Riau, Indonesia. Talak Mamak tribe from Indragiri Hulu empirically use the leaves and fruits of this plant to treat diarrhea. Previous studies showed that various plants from the same genus, such as $M$. gigantea, $M$. pruinosa, $M$. tanarius and $M$. triloba had strong antimicrobial activity against $S$. aureus. ${ }^{2,3}$ Salah et al reported that M. monandra possessed anti-fungal activity. ${ }^{4}$ Nevertheless, the antimicrobial activity from $M$. bancana had not been previously reported.

Therefore, this study was conducted to

Corresponding author: Hilwan Y. Teruna. Department of Chemistry, Faculty of Mathematics and Natural Sciences,

University of Riau, Pekanbaru, Riau, Indonesia. Email: hyteruna@unri.ac.id

Received: 8 March 2019. Revised: 29 March 2019. Published: 25 April 2019. 
evaluate the anti-bacterial and anti-fungal activities of $M$. bancana against human pathogenic microbes, i.e., E. coli, S. aureus, and C. albicans.

\section{Methods}

\section{Extract preparation}

$M$. bancana leaves were collected from Indragiri Hulu, Province of Riau, in March 2018. Plant determination was conducted at Department of Biology, Faculty of Mathematics and Natural Sciences, University of Riau. The leaves were cleaned, air-dried, and powdered. Subsequently, 20 $\mathrm{g}$ of the leaves powder were cold extracted using n-hexane, dichloromethane (DCM), ethyl acetate (EtOAc), methanol and ethanol for $3 \times 24$ hours, respectively. The filtrate was collected and concentrated using rotary evaporator.

\section{Anti-microbial activity}

The anti-microbial activities of the extracts against $S$. aureus, E. coli ATCC 35218, and C. albicans ATCC 10231 were conducted using microdilution method. ${ }^{5}$ The extracts were dissolved in dimethyl sulfoxide (DMSO) in the concentration of $1000 \mu \mathrm{g} /$ ml. Amoxsan ${ }^{\circledR}$, cefadroxil and ketokenazole at $1000 \mu \mathrm{g} / \mathrm{ml}$ were used as positive control, while DMSO was used as negative control. Precultures of the tested microorganisms were made by inoculating $25 \mathrm{ml}$ of nutrient broth medium for bacteria (WP medium for fungus) and incubated for 18 hours at 37 ${ }^{0} \mathrm{C}$ for bacteria (4 days at room temperature for fungus). Subsequently, the cell density was adjusted to $107 \mathrm{CFU} / \mathrm{ml}^{6}{ }^{6}$ Microbial suspension of $20 \mu \mathrm{l}$ was distributed in each well containing extract, nutrient broth, and resazurin. The plate was incubated at 37 ${ }^{0} \mathrm{C}$ for $24 \mathrm{~h}$ for the bacteria or 4 days for the fungus and the optical density of each was measured by using microplate reader. The experiment was run in three replicates.

\section{Data analysis}

The inhibition activity was calculated using the formula:

$$
\begin{aligned}
& \% \text { growth }=\frac{\text { A control }- \text { A sample }}{\text { A control }} \times 100 \\
& \% \text { inhibition }=100-\% \text { growth }
\end{aligned}
$$

\section{Results and Discussion}

In this study, anti-bacterial and anti-fungal activities of $M$. bancana leaves extracts were evaluated against three pathogenic microbes (S. aureus, E. Coli, and C. albicans) using microdilution method. This method was used because it has several advantages, e.g., can be used to analyzed several different samples at one time, requires small amount of samples, and has high sensitivity. ${ }^{7}$

In this assay, the resazurin was added as microbial growth indicator. The addition of resazurin in the assay can predict the presence of visual anti-microbial activity (qualitative) through colour change. A compound which has anti-microbial activity changes from pink to blue, while those which does not have activity or weak activity stays pink. This reaction is resulted from the activity of oxyreductase in the microbe that converts blue resazurin into pink resofurin. ${ }^{5}$ Furthermore, the anti-microbial activity can be determined by measuring the optical density to observe the inhibition growth.

The anti-microbial activity from various extracts of M.bancana leaves is presented in the Table 1. All extracts showed high inhibitory with $100 \%$ inhibition, except ethanol extract (72.8\%). Nevertheless, methanol and ethanol extracts showed $100 \%$ inhibitory activity against $E$. coli, while the lowest activity was shown by n-hexane extract ( 45.2\%). All extracts exhibited 100\% inhibitory activity against $C$. albicans. 
Table 1. Anti-Microbial Activity from Various Extracts of M. bancana Leaves

\begin{tabular}{lccc}
\hline \multicolumn{1}{c}{$\begin{array}{c}\text { Sample } \\
(\mathbf{1 0 0 0} \boldsymbol{\mu g} / \mathbf{m l})\end{array}$} & \multicolumn{3}{c}{ Inhibition (\%) } \\
\cline { 2 - 4 } & S. aureus & E. coli & C. albicans \\
\hline n-hexane extract & 100 & 45.2 & 100 \\
EtOAc extract & 100 & 72.1 & 100 \\
DCM extract & 100 & 69.4 & 100 \\
Methanol extract & 100 & 100 & 100 \\
Ethanol extract & 72.8 & 100 & 100 \\
Amoxsan ${ }^{\circledR}$ & 100 & 100 & - \\
Cefadroxil & 100 & 100 & - \\
Ketoconazole & - & - & 100 \\
\hline
\end{tabular}

All extracts exhibited high inhibition activity toward Gram-positive bacteria. These results are in accordance with previous study by Othman et al showing that Gram-negative microorganisms are typically more resistant to antimicrobial agents than Gram-positive bacteria. ${ }^{8}$ This has long been explained by the presence of an outer membrane permeability barrier in Gram-negative bacteria, which limits the access of the antimicrobial agents to their targets in the bacterial cells. Furthermore, all extracts showed high inhibition activity against $C$. albicans with $100 \%$ inhibition, similar with ketoconazole as positive control. Strong anti-fungal activity of the extract is caused by the activity of compounds that prevent the synthesis of ergosterol by inhibiting the P450 enzyme. This will cause the depletion of ergosterol, which can lead to a change in membrane permeability and cell membrane damage. ${ }^{9}$ Nevertheless, the further investigation is needed to investigate the mode of action of the extracts towards the fungal.

\section{Conclusion}

Leaves extract of M. bancana is a potential source of anti-bacterial and anti-fungal agents.

\section{Acknowledgement}

The authors thank Ministry of Research,
Technology, and Higher Education of the Republic of Indonesia for funding this project.

\section{Funding}

Postgraduate grant research from the Ministry of Research, Technology, and Higher Education of the Republic of Indonesia 2018 (No. 339/UN.19.5.1.3/PP/2018).

\section{Conflict of interest}

None declared.

\section{References}

1. Abdallah EM. Plants: An alternative source for antimicrobials. Journal of Applied Pharmaceutical Science. 2011;1(6):16-20.

2. Panda SK, Padhi L, Leyssen $\mathrm{P}$, et al. Antimicrobial, anthelmintic, and antiviral activity of plants traditionally used for treating infectious disease in the similipal biosphere reserve, Odisha, India. Frontiers in Pharmacology. 2017;8:658.

3. Lim TY, Lim YY, Yule CM. Evaluation of antioxidant, antibacterial and anti-tyrosinase activities of four Macaranga species. Food Chemistry. 2009; 114(2):594-599.

4. Salah MA, Bedir E, Toyang NJ, et al.Anti-fungal clerodane diterpenes from Macaranga monandra (L) Muell. et Arg. 
(Euphorbiaceae). Journal of Agricultural and Food Chemistry. 2003;51(26):76077610.

5. Elshikh M, Ahmed S, Funston S, et al. Resazurin-based 96-well plate microdilution method for the determination of minimum inhibitory concentration of biosurfactants. Biotechnology Letters. 2016;38(6):10151019.

6. Martins IM, Cortés JCG, Munoz J, et al. Differential activities of three families of specific $\beta(1,3)$ glucan synthase inhibitors in wild-type and resistant strains of fission yeast. The Journal of Biological Chemistry. 2011;286(5):3484-3496.

7. Klančnik A, Piskernik S, Jeršek B, et al. Evaluation of diffusion and dilution methods to determine the antibacterial activity of plant extracts. Journal of Microbiological Methods. 2010;81(2):121-126.

8. Lode HM. Clinical impact of antibioticresistant Gram-positive pathogens. Clinical Microbiology Infection. 2009;15: 212-217.
9. Dhamgaye S, Devaux F, Vandeputte P, et al. Molecular mechanisms of action of herbal anti-fungal alkaloid berberine, in Candida albicans. PLoS One. 2014;9(8):e104554.

10. Soliman SSM, Semreen MH, El-Keblawy AA, et al. Assessment of herbal drugs for promising anti-Candida activity. BMC Complementary and Alternative Medicines. 2017;17(1):257.

11. Chen C, Long L, Zhang F, et al. Antifungal activity, main active components and mechanism of Curcuma longa extract against Fusarium graminearum. PLoS One. 2018;13(3):e0194284. 